\title{
PENGARUH KEPEMIMPINAN DAN KEPUASAN KERJA TERHADAP DISIPLIN KERJA PADA BALAI DIKLAT LINGKUNGAN HIDUP DAN KEHUTANAN PEMATANGSIANTAR
}

\author{
Oleh: \\ Nina Arsilah \\ S1 Manajemen \\ Darwin Lie, Marisi Butarbutar, Lora Ekana Nainggolan
}

Abstraksi

Adapun rumusan masalah penelitian ini adalah bagaimana pengaruh kepemimpinan dan kepuasan kerja terhadap disiplin kerja pada Balai Diklat Lingkungan Hidup dan Kehutanan Pematangsiantar. Penelitian ini menggunakan desain penelitian kepustakaan dan penelitian lapangan. Populasi pada penelitian ini adalah pegawai Balai Diklat Lingkungan Hidup dan Kehutanan Pematangsiantar berjumlah 57 pegawai. Data yang digunakan adalah data dengan cara kualitatif dan data kuatitatif, dan teknik pengumpulan data dengan cara kuesioner, wawancara dan dokumentasi. Kemudian teknik analisa data menggunakan metode deskriptif kualitatif dan metode deskriptif kuantitatif.

Hasil analisis dari regresi linier berganda yaitu $\hat{Y}=26,243+1,232 X_{1}+0,681 X_{2}$, artinya kepemimpinan dan kepuasan kerja berpengaruh positif terhadap disiplin kerja. Hubungan ketiga variabel adalah kuat, yaitu $\mathrm{r}=$ 0,752. Dari koefisien determinasi dapat dijelaskan tinggi rendahnya disiplin kerja 56,5\%, dan sisanya 43,5\% dijelaskan oleh faktor lainnya yang yang tidak dibahas dalam penelitian ini. Dari hasil pengolahan dan perhitungan kuesioner, penulis mendapatkan kesimpulan bahwa kepemimpinan dan kepuasan kerja yang diterapkan Balai Diklat Lingkungan Hidup dan Kehutanan Pematangsiantar berpengaruh positif dan signifikan terhadap kinerja pegawai. Hal ini dibuktikan melalui uji hipotesis secara simultan, dimana hasil uji $\mathrm{f}_{\text {hitung }}(35,062)$ $>\mathrm{f}_{\text {tabel }}(3,17)$ dengan taraf signifikansi $0,000<$ alpha 0,05 .

Kata Kunci: Kepemimpinan, Kepuasan Kerja dan Disiplin Kerja

\section{Abstraction}

The formulation of this research problem is how the influence of Leadership and Job Satisfaction on Work Discipline at Balai Diklat Lingkungan Hidup dan Kehutanan Pematangsiantar. The research method used in this paper is literature research and field research. Its population is employees of Balai Diklat Lingkungan Hidup dan Kehutanan Pematangsiantar amounted to 57 people. The data used are data by qualitative and qualitative data, and data collection techniques by questionnaire, interview and documentation. Then the technique of data analysis using qualitative descriptive method and quantitative descriptive method.

Results of analysis of multiple linier regression is $\hat{\mathrm{Y}}=26,243+1,232 \mathrm{X}_{1}+0,681 \mathrm{X}_{2}$, means there is a positive influence between leadership and job satisfaction on work discipline. The strength of the relationship between the three variables is strong, is $r=0,752$. From the coefficient of determination can be explained high low work discipline $56,5 \%$, and the remaining $43,5 \%$ explained by other factors that are not discussed in this study. From the results of processing and calculation of the questionnaire, the authors get the conclusion that the leadership and job satisfaction applied Balai Diklat Lingkungan Hidup dan Kehutanan Pematangsiantar have a positive and significant effect on work discipline. This is proven by hypothesis testing simultaneously, where the test result $f_{\text {hitung }}(35,062)>f_{\text {hitung }}(3,17)$ with significance level $0,000<$ alpha 0,05 .

\section{Keywords: Leadership, Job Satisfaction And Work Discipline}

\section{A. PENDAHULUAN}

\section{Latar Belakang Masalah}

Sumber daya manusia sebagai salah satu factor produksi terpenting yang sangat berpengaruh terhadap pencapaian tujuan organisasi. Karena faktor inilah yang melakukan penggunaan faktor-faktor produksi yang lain dalam perusahaan, maka organisasi perlu memberikan perhatian yang cukup pada sumber daya manusianya agar tujuan yang ingin dicapai benar-benar terwujud sesuai dengan yang diharapkan.

Balai Pendidikan dan Pelatihan Kehutanan (Balai Diklat Lingkungan Hidup dan Kehutanan) Pematangsiantar, merupakan salah satu balai pelatihan yang berada di bawah Kementerian Kehutanan. Fungsi dan tugas penyelenggara diklat kehutanan meliputi kegiatan pengkoordinasian, pembinaan dan pelaksanaan diklat di lingkunganDepartemen Kehutanan, tentunya diharapkan memiliki pegawai sebagai sumber daya manusia yang memiliki disiplin kerja yang baik.

Pegawai negeri sipil menerapkan disiplin kerja berdasarkan Peraturan Pemerintah No. 53 Tahun 2010. Disiplin kerja diukur dengan dua dimensi yaitu kewajiban yang harus dijalankan dan larangan-larangan yang harus dijauhi. Salah satu faktor yang mempengaruhi disiplin kerja adalah kepemimpinan.

Pemimpin merupakan orang yang akan menggerakkan serta mengarahkan organisasi tersebut untuk mencapai tujuan organisasi. Adapun dimensi kepemimpinan yaitu faktor situasi lingkungan kerja, 
faktor karakteristik pegawai, dan faktor karakteristik pemimpin.

Faktor lain yang mempengaruhi disiplin kerja adalah kepuasan kerja. Adapun dimensi kepuasan kerja yaitu, gaji, rekan kerja, atasan atau pimpinan, pekerjaan itu sendiri, promosi, dan lingkungan kerja.

\section{Rumusan Masalah}

a. Bagaimana gambaran kepemimpinan, kepuasan kerja, dan disiplin kerja pada Balai Diklat Lingkungan Hidup dan Kehutanan Pematangsiantar.

b. Bagaimana pengaruh kepemimpinan dan kepuasan kerja terhadap disiplin kerja pada Balai Diklat Lingkungan Hidup dan Kehutanan Pematangsiantar baik secara simultan maupun parsial.

\section{Tujuan Penelitian}

a. Untuk mengetahui gambaran kepemimpinan, kepuasan kerja, dan disiplin kerja pada Balai Diklat Lingkungan Hidup dan Kehutanan Pematangsiantar.

b. Untuk mengetahui pengaruh kepemimpinan dan kepuasan kerja terhadap disiplin kerja pada Balai Diklat Lingkungan Hidup dan Kehutanan Pematangsiantar baik secara simultan maupun parsial.

\section{Metode Penelitian}

Lokasi atau tempat penelitian ini dilakukan di Balai Diklat Lingkungan Hidup dan Kehutanan Pematangsiantar yang berada di Jalan Bali No. 12 Pematangsiantar. Pada penelitian ini yang menjadi populasi adalah pegawai Balai Diklat Lingkungan Hidup dan Kehutanan Pematangsiantar sebanyak 57 orang. Seluruh pegawai yang berjumlah 57 orang akan menjadi sampel sebagai responden untuk menjawab kuesioner yang penulis sebarkan, mengingat jumlahnya kurang dari 100 (seratus) orang dan ketersediaan waktu penulis serta untuk keakuratan hasil penelitian.

Adapun desain penelitian yang digunakan dalam penulisan skripsi ini adalah Penelitian Kepustakaan (Library Research) dan Penelitian Lapangan (Field Research). Teknik pengumpulan data yang dilakukan penulis dalam penelitian ini adalah berupa Kuesioner, Wawancara dan Dokumentasi. Adapun jenis data yang digunakan dalam penelitian ini adalah jenis data kualitatif dan data kuantitatif. Hasil data yang diperoleh dari lapangan akan dianalisis secara deskriptif baik bersifat kualitatif dan kuantitatif.

\section{B. LANDASAN TEORI}

\section{Manajemen dan Manajemen Sumber Daya} Manusia

Menurut Daft (2002:8), manajemen adalah pencapaian tujuan organisasi dengan cara yang efektif melalui perencanaan, pengorganisasian, pengarahan dan pengendalian sumber daya organisasi. Sedangkan menurut Griffin (2004:8), manajemen adalah suatu rangkaian aktivitas (termasuk perencanaan dan pengambilan keputusan, pengorganisasian, kepemimpinan, dan pengendalian) yang diarahkan pada sumber-sumber daya organisasi (manusia, finansial, fisik, dan informasi) untuk mencapai tujuan organisasi dengan cara efektif dan efisien. Menurut Handoko (2002:8), manajemen adalah suatu proses perencanaan, pengorganisasian, pengarahan, dan pengendalian serta pengawasan kegiatan organisasi dan penggunaan sumber daya manusia lainnya agar tercapai tujuan organisasi.

Menurut Mathis and John (2006:3), manajemen sumber daya manusia adalah rancangan sistem-sistem formal dalam sebuah organisasi untuk memastikan penggunaan bakat manusia secara efektif dan efisien guna mencapai tujuan organisasi. Menurut Bangun (2012:6), manajemen sumber daya manusia adalah suatu proses perencanaan, pengorganisasian, penyusunan staf, pengendalian dan pengawasan terhadap pengadaan, pengembangan, pemberian kompensasi, pengintegrasian, pemeliharaan dan pemisahan tenaga kerja untuk mencapai tujuan organisasi. Sedangkan menurut Mondy (2008:4), manajemen sumber daya manusia adalah pemanfaatan sejumlah individu untuk mencapai tujuan organisasi.

Menurut Mondy (2008:4), fungsi-fungsi manajemen sumber daya manusia adalah sebagai berikut:

a. Penyediaan Staf (Staffing)

Penyediaan Staf merupakan proses yang menjamin suatu organisasi untuk selalu memiliki jumlah karyawan yang tepat sesuai dengan keahlian-keahlian yang memadai dalam pekerjaan dan waktu yang tepat untuk mencapai tujuan organisasi.

b. Kompensasi

Kompensasi yaitu semua yang mencakup imbalan total yang diberikan kepada karyawan sebagai timbal balik untuk jasa mereka.

c. Pengembangan Sumber Daya Manusia

Pengembangan Sumber Daya Manusia adalah fungsi manajemen sumber daya manusia yang tidak hanya terdiri dari pelatihan dan pengembangan namun juga aktivitas-aktivitas perencanaan dan pengembangan karir individu, pengembangan organisasi dan penilaian kinerja.

d. Hubungan Karyawan dan Buruh

Dalam sebuah organisasi, serikat pekerja mewakili keinginan para karyawan perusahaan.Aktivitas sumber daya manusia disebut sebagai hubungan industrial untuk melakukan perlindungan kolektif.

e. Keselamatan dan Kesehatan

Keselamatan adalah perlindungan bagi karyawan dari luka-luka yang disebabkan kecelakaan yang terkait dengan pekerjaan.Kesehatan adalah bebasnya karyawan dari sakit secara fisik maupun emosi.

\section{Kepemimpinan}


Menurut Robbins dan Mary (2010:147), kepemimpinan merupakan suatu proses memimpin sebuah grup dan mempengaruhi grup mencapai tujuan grup. Menurut Northouse (2013:5), kepemimpinan adalah proses dimana individu memengaruhi sekelompok individu untuk mencapai tujuan bersama. Sedangkan menurut Luthans (2006:638), kepemimpinan adalah sekelompok proses, kepribadiaan, pemenuhan, perilaku tertentu, persuasi, wewenang, pencapaian tujuan, interaksi, perbedaan peran, inisiasi struktur, dan kombinasi dari dua atau lebih dari hal-hal tersebut.

Menurut Rivai (2003:43), ada tiga faktor yang mempengaruhi kepemimpinan yaitu sebagi berikut:

a. Faktor situasi lingkungan kerja

Situasi lingkungan kerja sangat berpengaruh terhadap masalah yang dihadapi terhadap pimpinan dalam pengambilan keputusan.

b. Faktor karakteristik pegawai

Artinya pegawai memiliki beragam karakteristik seperti pendidikan, pengalaman kerja, motivasi dan tanggung jawab terhadap pekerjaan.

c. Faktor karakteristik pemimpin

Merupakan salah satu faktor yang penting dalam pengambilan keputusan. Seorang pemimpin harus bisa menafsirkan secara jelas kebutuhan yang diinginkan oleh karyawan

\section{Kepuasan Kerja}

Luthans (2005:243), mengemukakan bahwa kepuasan kerja adalah hasil dari persepsi pegawai mengenai seberapa baik pekerjaan mereka memberikan hal yang dinilai penting.Menuru Sutrisno (2009:75), kepuasan kerja merupakan perasaan senang atau tidak senang pekerja dalam memandang dan menjalankan pekerjaannya. Apabila seseorang senang terhadap pekerjaannya, maka orang tersebut puas terhadap pekerjaannya. Sedangkan menurut Robbins dan Mary (2007:52), Kepuasan kerja yaitu sikap umum individual terhadap pekerjaannya. Walaupun kepuasan kerja merupakan sikap bukan perilaku, ini adalah suatu hasil yang memerlukan perhatian banyak manajer karena karyawan yang puas lebih cenderung untuk menunjukkan pekerjaannya dan untuk tetap bersama organisasi tersebut.

Menurut Hariandja (2006:291), ada elemen yang mempengaruhi kepuasan kerja pegawai, yaitu:

a. Gaji

Upah atau gaji merupakan jumlah balas jasa finansial yang diterima pegawai dan tingkat dimana hal ini dipandang sebagai suatu hal yang adil dalam organisasi.

b. Rekan Kerja

Kerja sama rekan kerja atau kelompok kerja adalah sumber kepuasan kerja bagi pekerja secara individual. Baiknya hubungan antara rekan kerja sangat besar artinya apabila rangkaian pekerjaan tersebut memerlukan kerja sama tim yang tinggi.

c. Atasan

Kepemimpinan yang ditetapkan oleh seorang manajer dalam organisasi dapat menciptakan integrasi yang serasi dan mendorong gairah kerja karyawan untuk mencapai sasaran yang maksimal.

d. Pekerjaan Itu Sendiri

Adanya kesesuaian pekerjaan dengan keterampilan diharapkan mampu mendorong karyawan untuk menghasilkan kinerja yang baik.

e. Promosi

Promosi dimaksud adalah seseorang dapat merasakan adanya kemungkinan yang besar untuk naik jabatan atau tidak, proses kenaikan jabatan kurang terbuka atau terbuka.

f. Lingkungan Kerja

Kondisi kerja, apabila kondisi kerja karyawan baik (bersih, menarik, aman, dan lingkungan kerja yang menyenangkan) akan membuat mereka mudah menyelesaikan pekerjannya.

\section{Disiplin Kerja}

Menurut Sutrisno (2011:97), disiplin kerja didefinisikan sebagai media yang digunakan para karyawan untuk berkomunikasi agar mereka mampu untuk mengubah suatu perilaku serta sebagai suatu upaya untuk meningkatkan kesadaran dan kesediaan seseorang menaati semua peraturan perusahaan dan semua norma-norma sosial yang berlaku. Menurut Rivai (2009:599), disiplin kerja adalah suatu alat yang digunakan para manajer untuk berkomunikasi denagn pegawai agar mereka bersedia untuk mengubah suatu upaya untuk meningkatkan kesadaran dan kesediaan seseorang mentaati semua peraturan perusahaan dan norma-norma social yang berlaku. Sedangkan menurut Simamora (2004:610), mengemukakan bahwa disiplin (discipline) adalah prosedur yang mengoreksi atau menghukum bawahan melanggar peraturan atau prosedur.

Berdasarkan Peraturan Pemerintah Republik Indonesia Nomor 53 Tahun 2010 Tentang Disiplin Pegawai Negeri Sipil, Kewajiban serta larangan tersebut adalah sebagai berikut:

a. Setiap pegawai negeri sipil (PNS) wajib:

1) Mengucapkan sumpah/ janji PNS

2) Mengucapkan sumpah/ janji jabatan

3) Setia dan taat sepenuhnya kepada Pancasila, Undang-Undang Dasar Negara Republik Indonesia Tahun 1945, Negara Kesatuan Republik Indonesia, dan Pemerintah

4) Menaati segala ketentuan peraturan perundang-undangan melaksanakan tugas kedinasan yang dipercayakan kepada PNS dengan penuh pengabdian, kesadaran, dan tanggung jawab

5) Menjunjung tinggi kehormatan negara, Pemerintah, dan martabat PNS

6) Mengutamakan kepentingan negara daripada kepentingan sendiri, seseorang dan atau golongan

7) Memegang rahasia jabatan yang menurut sifatnya atau menurut perintah harus dirahasiakan

8) Bekerja dengan jujur, tertib, cermat, dan bersemangat untuk kepentingan Negara 
9) Melaporkan dengan segera kepada atasannya apabila mengetahui ada hal yang dapat membahayakan atau merugikan negara atau Pemerintah terutama di bidang keamanan, keuangan, dan materiil

10) Masuk kerja dan menaati ketentuan jam kerja

11) Mencapai sasaran kerja pegawai yang ditetapkan

12) Menggunakan dan memelihara barang-barang milik negara dengan sebaik-baiknya

13) Memberikan pelayanan sebaik-baiknya kepada masyarakat

14) Membimbing bawahan dalam melaksanakan tugas

15) Memberikan kesempatan kepada bawahan untuk mengembangkan karier

16) Menaati peraturan kedinasan yang ditetapkan oleh pejabat yang berwenang.

b. Setiap pegawai negeri sipil (PNS) dilarang:

1) Menyalahgunakan wewenang

2) Menjadi perantara untuk mendapatkan keuntungan pribadi dan/atau orang lain dengan menggunakan kewenangan orang lain

3) Tanpa izin Pemerintah menjadi pegawai atau bekerja untuk negara lain dan/atau lembaga atau organisasi lnternasional

4) Bekerja pada perusahaan asing, konsultan asing, atau lembaga swadaya masyarakat asing

5) Memiliki, menjual, membeli, menggadaikan, menyewakan, atau meminjamkan barangbarang baik bergerak atau tidak bergerak, dokumen atau surat berharga milik negara secara tidak sah

6) Melakukan kegiatan bersama dengan atasan, teman sejawat, bawahan, atau orang lain di dalam maupun diluar lingkungan kerjanya dengan tujuan untuk keuntungan pribadi, golongan, atau pihak lain, yang secara langsung atau tidak langsung merugikan negara

7) Memberi atau menyanggupi akan memberi sesuatu kepada siapapun baik secara langsung atau tidak langsung dan dengan dalih apapun untuk diangkat dalam jabatan

8) Menerima hadiah atau suatu pemberian apa saja dari siapapun juga yang berhubungan dengan jabatan dan/atau pekerjaannya

9) Bertindak sewenang-wenang terhadap bawahannya

10) Melakukan suatu tindakan atau tidak melakukan suatu tindakan yang dapat menghalangi atau mempersulit salah satu pihak yang dilayani sehingga mengakibatkan kerugian bagi yang dilayani

11) Menghalangi berjalannya tugas kedinasan

12) Memberikan dukungan kepada calon Presiden/ Wakil Presiden, Dewan Perwakilan Rakyat, Dewan Perwakilan Daerah, atau Dewan Perwakilan Rakyat Daerah

13) Memberikan dukungan kepada calon Presiden / wakil Presiden
14) Memberikan dukungan kepada calon anggota Dewan Perwakilan Daerah atau calon Kepala Daerah/ Wakil Daerah dengan cara memberikan surat dukungan disertai foto kopi Kartu Tanda Penduduk atau Surat Keterangan Tanda Penduduk sesuai peraturan perundangundangan.

15) Memberikan dukungan kepada calon Kepala Daerah/ Wakil Kepala Daerah.

\section{Pengaruh Kepemimpinan dan Kepuasan} Kerja Terhadap Disiplin Kerja

Dalam era globalisasi sekarang ini yang sarat dengan tantangan, persaingan, perkembangan ilmu pengetahuan dan teknologi menuntut para pimpinan untuk menerapkan disiplin kerja terhadap bawahannya untuk mematuhi peraturan, prosedur dan kebijakan yang ada, sehingga dapat menghasilkan kinerja yang baik. Kepemimpinan adalah hubungan yang ada dalam diri seseorang atau pemimpin, mempengaruhi orang lain untuk bekerja secara sadar dalam hubungan tugas untuk mencapai tujuan yang diinginkan.

Menurut Kartono (2000:115), kepemimpinan berpengaruh terhadap disiplin kerja pegawai, karena kepemimpinan merupakan kegiatan mempengaruhi dan mengarahkantingkah laku bawahan atau orang lain untuk mencapai tujuan organisasi atau kelompok. Dengan adanya kepemimpinan diharapkan adanya hubungan yang sinergis antara masing-masing kepentingan tersebut. Namun demikian keberhasilan yang dicapai oleh perusahaan tidak hanya ditentukan oleh faktor kecakapan dan kemampuan pemimpin, tetapi juga dipengaruhi oleh dampak yang ditimbulkan oleh adanya kegiatan kepemimpinan tersebut yaitu disiplin kerja pegawai yang merupakan ketaatan yang terus menerus dari pegawai terhadap peraturan-peraturan yang dibuat oleh perusahaan.

Mathis dan John (2011:46), menyatakan bahwa kepuasan kerja sangat berperan dalam membentuk kedisiplinan, komitmen dan kinerja karyawan yang kemudian berpengaruh terhadap kualitas layanan dalam usaha mencapai tujuan perusahaan.Kepuasan kerja dapat mempengaruhi disiplin kerja pegawai kearah yang lebih baik, hal ini disebabkan karena pegawai telah mencapai kepuasan psikologis yang memunculkan sikap positif dari karyawan.

\section{PEMBAHASAN}

1. Analisis

\section{a. Deskriptif Kualitatif}

Analisis deskriptif dimaksudkan untuk mendapatkan gambaran atau deskripsi mengenai tanggapan dari pegawai mengenai pengaruh kepemimpinan dan kepuasan kerja terhadap disiplin kerja pada Balai Diklat Lingkungan Hidup dan Kehutanan Pematangsiantar. Setelah pengujian data, maka langkah selanjutnya adalah peneliti melakukan pengkajian analisis kualitatif sebagai gambaran fenomena dari variabel penelitian pada saat sekarang 
ini. Adapun penetapan kriteria nilai data-data jawaban dari responden tersebut dimasukkan ke dalam kelas-kelas interval, dimana penentuan intervalnya menggunakan rumus sebagai berikut:

Interval kelas $=\frac{\text { Nilai Tertinggi }- \text { Nilai Terendah }}{\text { (jumlah kelas interval) }}$

$=\frac{5-1}{5}$

$=\frac{4}{5}$

$=0,8$

Dari rumus di atas, diperoleh nilai interval kelas = 0,8, sehingga berlaku ketentuan kategori dengan hasil sebagai berikut:

Tabel 1

Nilai Interval dan Kategori Jawaban Responden.

\begin{tabular}{|c|c|}
\hline $\begin{array}{c}\text { Nilai } \\
\text { Interval }\end{array}$ & Kategori \\
$1,00-1,80$ & $\begin{array}{c}\text { Sangat Tidak Baik (STB) / Sangat } \\
\text { Puas (SP) }\end{array}$ \\
\hline $1,81-2,60$ & Tidak Baik (TB) / Tidak Puas (TP) \\
\hline $2,61-3,40$ & $\begin{array}{c}\text { Cukup Baik (CB) / Cukup Puas } \\
(\mathrm{CP})\end{array}$ \\
\hline $3,41-4,20$ & Baik (B) / Puas (P) \\
\hline $4,21-5,00$ & $\begin{array}{c}\text { Sangat Baik (SB) / Sangat Puas } \\
(\mathrm{SP})\end{array}$ \\
\hline
\end{tabular}

Sumber: data diolah

\section{1) Kepemimpinan pada Balai Diklat Lingkungan}

Hidup dan Kehutanan Pematangsiantar

Kepemimpinan adalah proses yang sangat penting dalam setiap organisasi, karena kepemimpinan inilah yang akan menentukan sukses tidaknya sebuah organisasi. Adapun dimensi kepemimpinan pada Balai Diklat Lingkungan Hidup dan Kehutanan Pematangsiantar adalah faktor situasi lingkungan kerja, faktor karakteristik pegawai, dan faktor karakteristik pemimpin. Faktor situasi lingkungan kerja, dapat dilihat dari, kurangnya ketegasan kepala balai dalam mengambil keputusan terutama yang menyangkut masalah disiplin pegawai.

Faktor karakteristik pegawai, dapat dilihat ketika kepala balai memberikan pekerjaan sesuai dengan kemampuan yang dimiliki pegawai dengan melihat hasil kerja yang sebelumnya. Faktor karakteristik pemimpin, dapat dilihat ketika pegawai mengalami kesulitan dalam tugas kedinasan, kepala balai mau membantu pegawai dalam menyelesaikan pekerjaan tersebut.

Berdasarkan hasil analisis deskriptif kualitatif tentang kemampuan intelektual diperoleh nilai rata-rata sebesar 3,93 dengan kriteria baik. Kemudian nilai rata-rata tertinggi sebesar 4,18 dengan kriteria baik, pada dimensi karakteristik pimpinan pada indikator dukungan yang diberikan pimpinan kepada pegawai. Sedangkan nilai terendah sebesar 3,37 dengan kriteria cukup baik pada dimensi karakteristik situasi lingkungan kerja pada indikator keberanian pimpinan mengambil keputusan.

\section{2) Kepuasan Kerja pada Balai Diklat Lingkungan Hidup dan Kehutanan Pematangsiantar}

Kepuasan kerja merupakan suatu keadaan dimana karyawan merasa puas atas apa yang dihasilkannya dari pekerjaan yang dilakukannya. Pada Balai Diklat Lingkungan Hidup dan Kehutanan Pematangsiantar, Kepuasan kerja menggunakan enam dimensi dalam meningkatkan kepuasan kerja yaitu, gaji, rekan kerja, pimpinan atau atasan, pekerjaan itu sendiri, promosi, lingkungan kerja.

Pada dimensi gaji, dapat dilihat dari instansi yang memberikan kenaikan gaji sesuai dengan tingkat pekerjaan pegawai masing-masing tetapi tidak menyalahi aturan yang ada pada instansi. Pada dimensi rekan kerja dapat dilihat dari para pegawai saling memberikan respon dan rasa peduli antar sesame rekan kerja. Pada dimensi atasan atau pimpinan dapat dilihat dari kepala balai selalu memberikan pengarahan serta bimbingan yang baik sehingga tidak ada lagi pegawai yang merasa kurang puas atas apa yang dilakukan kepala balai.

Pada dimensi pekerjaan itu sendiri dapat dilihat dari instansi yang kurang baik dalam pembagian tugas kepada para pegawai sehingga terjadi penumpukan pekerjaan. Pada dimensi promosi, dapat dilihat dari instansi memberikan promosi kenaikan jabatan berdasarkan lama bekerja dan prestasi yang diperoleh pegawai sehingga promosi dapat diberikan. Pada dimensi lingkungan kerja, dapat dilihat dari instansi memberikan fasilitas-fasilitas seperti teknologi untuk mendukung kinerja pegawai.

Berdasarkan hasil analisis deskriptif kualitatif tentang komunikasi diperoleh nilai rata-rata sebesar 4,01 yang berkriteria puas. Kemudian nilai rata-rata tertinggi sebesar 4,25 yang berkriteria sangat puas, pada dimensi gaji pada indikator tunjangan yang diterapkan instansi. Sedangkan nilai terendah sebesar 3,35 dengan kriteria cukup puas pada dimensi pekerjaan itu sendiri pada indicator pekerjaan yang anda kerjakan dalam instansi.

3) Disiplin Kerja pada Balai Diklat Lingkungan Hidup dan Kehutanan Pematangsiantar

Disiplin yaitu kesanggupan seorang Pegawai Negeri Sipil untuk menaati kewajiban dan menghindari larangan yang ditentukan dalam peraturan perundang-undangaan atau peraturan kedinasan yang apabila tidak ditaati atau dilanggar dijatuhkan sanksi. Adapun dimensi disiplin kerja pada Balai Diklat Lingkungan Hidup dan Kehutanan Pematangsiantar adalah menjalankan kewajiban dan menjauhi larangan.

Pada dimensi menjalankan kewajiban, hal ini disebabkan karena masih ada beberapa pegawai yang melanggar peraturan seperti datang terlambat untuk melakukan absensi pagi dan terlambat apel pagi, tidak mematuhi waktu kerja sesuai peraturan. Dimensi menjauhi larangan, dapat dilihat dari ada beberapa pegawai yang kurang baik dalam 
menggunakan barang-barang milik negara seperti menggunakan fasilitas mesin foto copy dan boros dalam menggunakan persedian alat tulis kantor.

Berdasarkan hasil analisis deskriptif kualitatif tentang kinerja pegawai diperoleh nilai rata-rata sebesar 3,97 dengan kriteria baik. Nilai rata-rata disiplin kerja tertinggi adalah 4,14 dengan kriteria baik pada dimensi menjalankan kewajiban dengan indikator menaati peraturan perundang-undangan dan menerima hadiah yang berhubungan dengan jabatan. Nilai rata-rata terendah pada disiplin kerja dilihat pada dimensi menjalankan kewajiban dengan indikator menaati ketentuan jam kerja dengan nilai rata-rata 3,37 dengan kriteria cukup baik.

\section{b. Deskriptif Kuantitatif}

\section{1) Analisis Regresi Linier Berganda}

Penelitian ini memiliki tujuan untuk menganalisis pengaruh kepemimpinan dan kepuasan kerja terhadap disiplin kerja. Analisis regresi linier berganda digunakan untuk mengetahui pengaruh variabel bebas $(\mathrm{X})$ dan variabel terikat $(\mathrm{Y})$, dimana $\mathrm{X} 1$ adalah kepemimpinan, $\mathrm{X} 2$ adalah kepuasan kerja dan $\mathrm{Y}$ adalah disiplin kerja.

Analisis dijalankan dengan melakukan tabulasi jabawan responden pada kuesioner yang telah dijalankan, sebagai berikut:

Tabel 2

Hasil Regresi Linier Berganda

\begin{tabular}{|l|r|r|r|}
\hline \multirow{2}{*}{ Model } & \multicolumn{2}{|c|}{ Coefficients $^{\boldsymbol{a}}$} \\
& \multicolumn{2}{|c|}{$\begin{array}{c}\text { Unstandardized } \\
\text { Coefficients }\end{array}$} & $\begin{array}{c}\text { Standardize } \\
\boldsymbol{d} \\
\text { Coefficients }\end{array}$ \\
\cline { 2 - 4 } & $\mathbf{B}$ & $\begin{array}{c}\text { Std. } \\
\text { Error }\end{array}$ & \multicolumn{1}{c|}{ Beta } \\
\hline $\begin{array}{l}\text { (Constant) } \\
\text { Kepemimpina } \\
\text { n }\end{array}$ & $\mathbf{2 6 , 2 4 3}$ & 12,096 & \\
$\begin{array}{l}\text { Kepuasan } \\
\text { Kerja }\end{array}$ &, $\mathbf{1 , 2 3 2}$ &, 394 &, 365 \\
\end{tabular}

a. Dependent Variable: Disiplin Kerja

Sumber : hasil pengolahan data primer

Dari hasil analisis regresi dengan SPSS diperoleh koefisien regresi $b_{1}$ sebesar 1,232 dan $b_{2}$ sebesar 0,681 sehingga dapat diketahui persamaan regresi yang diperoleh adalah : $\hat{\mathrm{Y}}=26,243+$ $1,232 \mathrm{X}_{1}+0,681 \mathrm{X}_{2}$, artinya terdapat pengaruh yang positif antara variabel kepemimpinan dan variabel kepuasan kerja terhadap disiplin kerja pada Balai Diklat Lingkungan Hidup dan Kehutanan Pematangsiantar.

\section{2) Analisis Koefisien Korelasi dan Koefisien Determinan (KD)}

Untuk menghitung kekuatan hubungan kepemimpinan dan kepuasan kerja terhadap disiplin kerja dilakukan analisis korelasi, berupa derajat atau kedalaman hubungan fungsional yang menjelaskan hubungan antara perubah, dinyatakan dengan koefisien korelasi yang disimbolkan dengan $r$. Nilai $r$ dapat dilihat melalui tabel berikut:
Tabel 3

Hasil Koefisien Korelasi dan Koefisien

Determinasi

Model Summary ${ }^{b}$

\begin{tabular}{|r|c|r|r|r|}
\hline Model & $\mathbf{r}$ & $\begin{array}{c}\boldsymbol{R} \\
\text { Square }\end{array}$ & $\begin{array}{c}\text { Adjusted } \\
\boldsymbol{R} \text { Square }\end{array}$ & $\begin{array}{c}\text { Std. Error } \\
\text { of the } \\
\text { Estimate }\end{array}$ \\
\hline 1 &, $\mathbf{7 5 2}$ &, $\mathbf{5 6 5}$ &, 549 & 8,383 \\
\hline
\end{tabular}

a. Predictors: (Constant), Variabel X

(Kepemimpinan Dan Kepuasan Kerja)

b. Dependent Variable: Variabel Y (Disiplin Kerja) Sumber : hasil pengolahan data

Dari tabel 3, didapat $r=0,752$ yang artinya terdapat hubungan yang kuat dan positif antara kepemimpinan dan kepuasan kerja dengan disiplin kerja pada Balai Diklat Lingkungan Hidup dan Kehutanan Pematangsiantar. Selanjutnya diperoleh koefisien determinasi Rsquare 0,565 artinya sebesar $56,5 \%$ proporsi disiplin kerja dijelaskan oleh kepemimpinan dan kepuasan kerja, sedangkan sisanya sebesar $43,5 \%$ dijelaskan variabel lain diluar penelitian ini.

\section{3) Uji Hipotesis}

a) Uji Simultan (Uji F)

Uji $F$ digunakan untuk mengetahui apakah variabel bebas (kepemimpinan dan kepuasan kerja) berpengaruh terhadap variabel terikat (disiplin kerja) secara bersama-sama atau simultan. Pengujian ini dilakukan untuk membandingkan antara $F_{\text {hitung dan }}$ $F_{\text {tabel }}$ pada taraf signifikansi sebesar $5 \%$ atau $\alpha=0,05$ dengan menggunakan program aplikasi SPSS, dapat dilihat dari tabel berikut:

\section{Tabel 4}

Perkiraan Nilai Fhitung

ANOVA $^{\mathrm{a}}$

\begin{tabular}{|c|r|c|c|c|c|}
\hline Model & $\begin{array}{c}\text { Sum of } \\
\text { Squares }\end{array}$ & $\begin{array}{c}\text { D } \\
\mathbf{f}\end{array}$ & $\begin{array}{c}\text { Mean } \\
\text { Squar } \\
\boldsymbol{e}\end{array}$ & $\mathbf{F}$ & Sig. \\
\hline Regression & 4927,83 & 2 & 246,91 & $\mathbf{3 5 , 0 6}$ & $\mathbf{, 0 0 0}$ \\
3 & & 6 & $\mathbf{2}$ & $\mathbf{b}$ \\
1 Residual & 3794,72 & 54 & 70,273 & & \\
8 & & & & \\
Total & 8722,56 & 56 & & & \\
1 & & & & \\
\hline
\end{tabular}

a. Dependent Variable: Disiplin Kerja (Y)

b. Predictors: (Constant), Kepemimpinan (X1),

Kepuasan Kerja (X2)

Sumber : hasil pengolahan data primer

Berdasarkan tabel 4 , diperoleh nilai $F_{\text {hitung }}$ sebesar 35,062 $>F_{\text {tabel }}$ sebesar 3,17 atau dengan taraf signifikan 0,000 lebih kecil dari alpha 0,05, maka $\mathrm{H}_{0}$ ditolak, artinya kepemimpinan dan kepuasan kerja berpengaruh positif dan signifikan terhadap disiplin kerja pada Balai Diklat Lingkungan Hidup dan Kehutanan Pematangsiantar.

b) Uji Parsial (Uji t) 
Untuk menghasilkan suatu kesimpulan yang valid, maka harus dilakukan uji hipotesis (uji t). Dari hasil perhitungan koefisien korelasi diketahui bahwa kepemimpinan, kepuasan kerja, dan disiplin kerja sangat berhubungan, untuk menguji kebenarannya maka dilakukan pengujian hipotesis dengan menggunakan program SPSS, dapat dilihat pada tabel berikut ini:

Tabel 5

Perkiraan Nilai thitung

Coefficients $^{\mathrm{a}}$

\begin{tabular}{|c|r|r|}
\hline Model & t & \multicolumn{1}{|c|}{ Sig. } \\
\hline (Constant) & $\mathbf{2 , 1 6 9}$ & $\mathbf{, 0 3 4}$ \\
Kepemimpinan (X1) & $\mathbf{3 , 1 2 7}$ & $\mathbf{, 0 0 3}$ \\
Kepuasan Kerja (X2) & $\mathbf{3 , 9 8 0}$ & $\mathbf{, 0 0 0}$ \\
\hline
\end{tabular}

a. Dependent Variable: Disiplin Kerja

Sumber : hasil pengolahan data primer

Dari tabel 5, dapat dilihat nilai thitung pada variabel kepemimpinan sebesar 3,127 lebih besar dari $t_{\text {tabel }}$ dengan $\mathrm{df}=\mathrm{n}-\mathrm{k}-1 \quad(57-2-1=54)$ sebesar 2,004, atau dengan taraf signifikan 0,003 lebih kecil dari aplha 0,05 , maka $\mathrm{H}_{0}$ ditolak, artinya kepemimpinan berpengaruh positif dan signifikan terhadap disiplin kerja pada Balai Diklat Lingkungan Hidup dan Kehutanan Pematangsiantar.

Sedangkan $t_{\text {hitung }}$ pada variabel kepuasan kerja sebesar 3,980 lebih besar dari $\mathrm{t}_{\text {tabel }}$ dengan $\mathrm{df}=$ n-k-1 (57-2-1=54) sebesar 2,004, atau dengan taraf signifikan 0,000 lebih kecil dari 0,05, maka $\mathrm{H}_{0}$ ditolak, artinyakepuasan kerjaberpengaruh positif dan signifikan terhadap disiplin kerja pada Balai Diklat Lingkungan Hidup dan Kehutanan Pematangsiantar.

\section{Evaluasi}

a. Kepemimpinan pada Balai Diklat Lingkungan Hidup dan Kehutanan Pematangsiantar

Berdasarkan dimensi yang digunakan dalam penelitian ini, hasil yang diperoleh adalah kepemimpinan yang ada pada Balai Diklat Lingkungan Hidup dan Kehutanan Pematangsiantar dapat dikatakan baik, hal itu dibuktikan berdasarkan hasil kuesioner yang diperoleh berada pada nilai rata-rata 3,93 yang berkriteria baik. Namun ada beberapa indikator dari dimensi-dimensi tersebut yang dinilai baik, tetapi masih ada di bawah nilai rata-rata.

Indikator yang memiliki nilai di bawah ratarata adalah pada indikator keterampilan pimpinan dalam mengambil keputusan dengan nilai rata-rata 3,89 yang berkriteria baik. Cara yang dilakukan pimpinan untuk mengatasi hal tersebut adalah memperbanyak membaca serta memanfaatkan teknologi untuk menambah wawasan. Pada indikator keberanian pimpinan dalam mengambil keputusan dengan nilai rata-rata 3,37 dengan kriteria cukup baik. Maka, sebaiknya kepala balai bersikap tegas dalam mengambil keputusan terutama saat pegawai melanggar peraturan, kepala balai memberikan sanksi atau hukuman sesuai dengan peraturan pemerintah yang sudah tertera denagn maksimal dan konsisten misalnya memberikan surat peringatan (SP).

Untuk indikator wawasan yang dimiliki pimpinan dengan nilai rata-rata 3,88 dengan kriteria baik. Hal yang dapat dilakukan kepala balai adalah selalu mencari berbagai informasi tentang hal-hal baru baik dari media cetak maupun elektronik agar kepala balai selalu tahu hal-hal baru yang akan diberikan kepada pegawai dan diterapkan dalam kemajuan instansi. Untuk indikator memilih pegawai yang tepat memiliki nilai rata-rata 3,84 dengan kriteria baik. Hal yang dapat dilakukan adalah kepala balai harus memilih pegawai berdasarkan kemampuan yang dimilikinya dengan melihat hasil kerja yang sebelumnya. Selanjutnya indikator melakukan pengawasan memiliki nilai rata-rata 3,86 denagn kriteria baik. Cara mengatasinya adalah, pimpinan sebaiknya melakukan pengawasan yang wajar dan tetap membiarkan pegawai mengeluarkan ide-ide yang dimilikinya, sehingga tidak membuat pegawai yang diberi delegasi merasa tertekan dan bisa lebih mengeluarkan kreatifitasnya.

\section{b. Kepuasan Kerja pada Balai Diklat Lingkungan Hidup dan Kehutanan Pematangsiantar}

Kepuasan kerja merupakan suatu keadaan dimana pegawai merasa puas atas apa yang dihasilkannya dan pekerjaan yang dilakukannya. Dimensi kepuasan kerja yang ada pada Balai Diklat Lingkungan Hidup dan Kehutanan Pematangsiantar dikatakan puas. Dapat dilihat dari hasil kuesioner yang dibagikan ke responden, secara keseluruhan dengan nilai puas berada pada nilai rata-rata 4,01 dengan kriteria jawaban puas.

Dari perhitungan rata-rata kepuasan kerja pegawai diperoleh nilai puas, namun ada beberapa indikator yang dibawah rata-rata dan masih perlu ditingkatkan seperti pada dimensi gaji. Pada indikator gaji yang diberikan sesuai dengan pekerjaan memiliki nilai rata-rata 3,88 dengan kriteria puas. Cara meningkatkannya, instansi memberikan kenaikan gaji yang sesuai dengan kesulitan pekerjaan yang dilakukan pegawai tersebut dan juga tidak menyalahi aturan yang ada pada instansi.

Selanjutnya pada dimensi rekan kerja dengan indikator perhatian antar sesama rekan kerja memiliki nilai rata-rata 3,98 dengan kriteria jawaban puas. Cara meningkatkannya, dengan memberikan respon dan meningkatkan rasa peduli antar sesama rekan kerja. Indikator dukungan yang diberikan rekan kerja dalam menyelesaikan pekerjaan memperoleh nilai 4,00 dengan kriteria jawaban puas. Cara mengatasinya yaitu dengan memberikan pekerjaan yang dilakukan secara bersama sehingga dukungan untuk menyelesaikan pekerjaan tersebut bisa lebih tinggi.

Pada dimensi pimpinan/atasan dengan indikator perhatian yang diberikan pimpinan 
memperoleh nilai rata-rata 3,93 dengan kriteria puas. Untuk meningkatkannya, pimpinan sebaiknya dapat memberikan pengarahan, bimbingan serta perhatian dengan baik sehingga pegawai tersebut tidak ada lagi yang merasa kurang puas atas apa yang dilakukan pimpinan. Selanjutnya untuk dimensi pekerjaan itu sendiri pada indikator sikap terhadap pekerjaan yang diberikan memperoleh nilai rata-rata 3,98 dengan kriteria jawaban puas.

Cara mengatasinya adalah, instansi sebaiknya memberikan perhatian, kompensasi, dan pengembangan karir dengan baik yang sesuai dengan kebutuhan pegawai tersebut sehingga setiap pekerjaan yang diberikan instansi dapat dikerjakan dengan sikap yang baik dan kepuasan dalam bekerja terus meningkat. Indikator pekerjaan yang anda kerjakan memperoleh nilai rata-rata 3,35 dengan kriteria jawaban cukup puas. Cara mengatasinya adalah, instansi sebaiknya membagi rata beban tugas yang diberikan kepada semua pegawai agar tidak terjadi penumpukan pekerjaan pada satu pegawai atau satu bagian saja. Sebab jika instansi tidak dapat membagi rata tugas dengan baik, maka pegawai akan terbebani dengan tenggang waktu untuk menyelesaikan pekerjaan tersebut sehinggga mempengaruhi kepuasan terhadap pekerja.

Selanjutnya pada dimensi promosi dengan indikator promosi berdasarkan kinerja memperoleh nilai rata-rata 3,98 dengan kriteria jawaban puas. Cara mengatasinya adalah, lebih banyak memberikan kesempatan promosi bagi pegawai yang berprestasi dalam pekerjaannya. Untuk indikator promosi diberikan berdasarkan lama bekerja memperoleh nilai rata-rata 3,96 dengan kriteria jawaban puas. Cara meningkatkannya adalah, memberikan kesempatan promosi bagi pegawai yang sudah lama bekerja untuk dapat meningkatkan prestasi kerja sehingga pemberian promosi dapat diberikan.

Pada dimensi lingkungan kerja dengan indikator lingkungan kerja di instansi memperoleh nilai rata-rata 3,98 dengan kriteria jawaban. Cara mengatasinya yaitu, menciptakan lingkungan kerja yang kondusif dan lebih aman lagi serta lebih memperhatikan tata letak ruang kantornya. Selanjutnya pada indikator fasilitas kerja yang diberikan, memperoleh nilai rata-rata 3,95 dengan kriteria jawaban puas. Cara mengatasinya adalah, instansi sebaiknya memberikan fasilitas-fasilitas seperti teknologi untuk mendukung kinerja para pegawai agar pekerjaan mereka terlaksana dengan puas.

\section{c. Disiplin Kerja pada Balai Diklat Lingkungan Hidup dan Kehutanan Pematangsiantar}

Dimensi disiplin kerja berdasarkan Peraturan Pemerintah Republik Indonesia Nomor 53 Tahun 2010 Tentang Disiplin Pegawai Negeri Sipil terdiri dari menjalankan kewajiban dan menjauhi larangan yang dalam penelitian ini memiliki nilai rata-rata 3,97 dengan kriteria baik. Namun ada beberapa indikator yang dinilai baik, tetapi masih dibawah nilai rata-rata disetiap dimensinya.
Indikator mengucapkan sumpah PNS berada pada nilai rata-rata 3,95 dengan kriteria baik serta mengucapkan sumpah jabatan dengan nilai rata-rata 3,89. Indikator melaksanakan tugas kedinasan dengan nilai rata-rata 3,88 yang berkriteria baik. Maka hal yang perlu dilakukan adalah memberikan teguran dari pimpinan bagi pegawai yang tidak melaksanakan tugas kedinasan.

Indikator memegang rahasia jabatan berada pada nilai rata-rata 3,95 dengan kriteria baik. Indikator melaporkan hal-hal yang dapat membahayakan negara berada pada nilai 3,96 dengan kriteria jawaban baik. Hal yang perlu dilakukan adalah memberikan sosialisasi dan selalu meningkatkan pentingnyamenjaga negara dari segala masalah yang disebabkan orang-orang dilingkungan kerja.

Indikator menaati ketentuan jam kerja berada pada nilai rata-rata 3,37 dengan kriteria jawaban cukup baik. Indikator sasaran kerja pegawai berada pada nilai 3,93 dengan kriteria jawaban baik. Hal yang dapat dilakukan adalah pimpinan sebaiknya memberikan pengawasan terhadap pegawai dan menegur pegawai yang menunda-nunda pekerjaannya. Indikator memberikan pelayanan yang baik untuk masyarakat berada pada nilai rata-rata 3,91 dengan kriteria jawaban baik. Hal yang dapat dilakukan adalah mengadakan pertemuan rutin dengan pegawai yang membahas pentingnya pegawai negeri sipil memberikan pelayanan kepada masyarakat untuk membangun kepercayaan masyarakat.

Indikator memberikan kesempatan bawahan mengembangkan berada pada nilai rata-rata 3,95 dengan kriteria jawaban baik. Hal yang harus dilakukan adalah memberikan kepercayaan pada bawahan dalam beberapa tugas dengan pendamping untuk melihat kemampuan pegawai yang akan berguna untuk karirnya dimasa depan. Indikator menaati peraturan kedinasan berada pada nilai ratarata 3,89 dengan kriteria jawaban baik. Hal yang dapat dilakukan adalah memberikan sanksi yang tegas dan konsisten bagi pegawai yang melanggar tugas kedinasan.

Indikator kesadaran pegawai untuk tidak bekerja dengan perusahaan asing berada pada nilai rata-rata 3,82 dengan kriteria jawaban baik. Indikator memiliki barang-barang miliki negara berada pada nilai rata-rata 3,93 dengan kriteria jawaban baik. Maka hal yang perlu dilakukan adalah memberikan teguran lisan maupun tertulis pada pegawai yang melakukannya.

Indikator bertindak sewenang-wenang terhadap bawahan berada pada nilai rata-rata 3,91 dengan kriteria jawaban baik. Indikator melakukan pelayanan yang baik bagi masyarakat berada pada nilai rata-rata 3,88 dengan kriteria baik. Indikator menjadi peserta kampanye dalam pemilu dengan menggunakan atribut PNS dengan nilai rata-rata 3,93 dan indikator membuat keputusan yang menguntungkan salah satu calon peserta pemilu 
dengan nilai rata-rata 3,95 dengan kriteria jawaban baik.

\section{KESIMPULAN DAN SARAN}

\section{Kesimpulan}

a. Hasil analisis deskriptif kualitatif tentang kepemimpinan memperoleh nilai rata-rata jawaban keseluruhan 3,93 dengan kriteria jawaban baik. Kemudian nilai rata-rata tertinggi sebesar 4,18 pada dimensi faktor karakteristik pimpinan dengan indikator dukungan yang diberikan pimpinan kapada pegawai. Selanjutnya nilai rata-rata terendah sebesar 3,37 pada dimensi faktor situasi lingkungan kerja dengan indikator keberanian pimpinan dalam mengambil keputusan.

b. Hasil analisis deskriptif kualitatif tentang kepuasan kerja memperoleh nilai rata-rata jawaban keseluruhan 4,01 dengan kriteria jawaban baik. Kemudian nilai rata-rata tertinggi sebesar 4,25 pada dimensi gaji di indikator pemberian tunjangan yang diberikan instansi. Sedangkan nilai rata-rata terendah sebesar 3,35 pada pekerjaan itu sendiri di indikator pekerjaan yang dikeerjakan dalam instansi.

c. Hasil analisis deskriptif kualitatif tentang disiplin kerja memperoleh nilai rata-rata jawaban keseluruhan 3,97 dengan kriteria jawaban baik. Kemudian nilai rata-rata tertinggi sebesar 4,12 pada dimensi menjalankan kewajiban dengan indikator menerapkan nilai pancasila dalam bekerja. Dan nilai rata-rata terendah sebesar 3,37 berada pada dimensi menjalankan kewajiban di indikator menaati ketentuan jam kerja.

d. Hasil analisis regresi linear berganda diperoleh nilai $\hat{Y}=26,243+1,232 X_{1}+0,681 X_{2}$ artinya terdapat pengaruh yang positif antara variabel kepemimpinan $\left(\mathrm{X}_{1}\right)$ dan variabel kepuasan kerja $\left(\mathrm{X}_{2}\right)$ terhadap disiplin kerja $(\mathrm{Y})$ pada Balai Diklat Lingkungan Hidup dan Kehutanan Pematangsiantar.

e. Hasil analisis korelasi didapat $r=0,752$ yang artinya terdapat hubungan yang kuat dan positif antara kepemimpinan dan kepuasan kerja terhadap disiplin kerja pada Balai Diklat Lingkungan Hidup dan Kehutanan Pematangsiantar. Selanjutnya diperoleh koefisien determinasi $\mathrm{R}$ square 0,565 artinya tinggi rendahnya kepemimpinan dan kepuasan kerja dapat dijelaskan sebesar $56,5 \%$ oleh disiplin kerja, selebihnya 43,5\% dijelaskan oleh faktorfaktor lain seperti kompensasi, pimpinan, etika kerja dan faktor-faktor lain yang tidak dibahas dalam penelitian ini.

f. Hasil pengujian hipotesis secara simultan dengan uji $\mathrm{F}$ diperoleh nilai $F_{\text {hitung }}$ sebesar 35,062 $>F_{\text {tabel }}$ $(0,05 ; 2$ VS 54) sebesar 3,17 atau dengan taraf signifikan $0,000<\alpha 0,05$, maka $\mathrm{H}_{0}$ ditolak, artinya kepemimpinan dan kepuasan kerja berpengaruh positif dan signifikan terhadap disiplin kerja pada Balai Diklat Lingkungan
Hidup dan Kehutanan Pematangsiantar secara simultan.

g. Hasil pengujian hipotesis secara parsial dengan uji $t$, terdapat pengaruh yang positif dan signifikan antara kepemimpinan dan kepuasan kerja terhadap disiplin kerja diperoleh nilai $t_{\text {hitung, }}$ pada variabel kepemimpinan $\left(\mathrm{X}_{1}\right)$ sebesar 3,127 $>t_{\text {tabel }}$ dengan $\mathrm{df}=\mathrm{n}-\mathrm{k}-1 \quad(57-2-1=54)$ sebesar 2,004, atau dengan taraf signifikan $0,003<\alpha$ 0,05 , maka $\mathrm{H}_{0}$ ditolak, artinya kepemimpinan berpengaruh positif dan signifikan terhadap disiplin kerja pada Balai Diklat Lingkungan Hidup dan Kehutanan Pematangsiantar secara parsial. Sedangkan $t_{\text {hitung }}$ pada variabel kepuasan kerja $\left(\mathrm{X}_{2}\right)$ sebesar 3,980 $>\mathrm{t}_{\text {tabel }}$ dengan $\mathrm{df}=\mathrm{n}-\mathrm{k}-1$ (57-2-1=54) sebesar 2,004, atau dengan taraf signifikan $0,000<\alpha \quad 0,05$, maka $\mathrm{H}_{0}$ ditolak, artinya kepuasan kerja berpengaruh positif dan signifikan terhadap disiplin kerja pada Balai Diklat Lingkungan Hidup dan Kehutanan Pematangsiantar secara parsial.

\section{Saran}

a. Kepemimpinan adalah proses yang sangat penting dalam setiap organisasi, karena kepemimpinan inilah yang akan menentukan sukses tidaknya sebuah organisasi. Jika sebuah organisasi mengalami kesuksesan, maka pimpinanlah yang mendapat anjungan jempol dan juga jika organisasi mengalami kegagalan, maka pimpinan yang mendapat kritik atau teguran.

b. Untuk meningkatkan kepuasan kerja pada Balai Diklat Lingkungan Hidup dan Kehutanan Pematangsiantar, instansi sebaiknya memberikan pekerjaan sesuai dengan jabatan dan pekerjaan yang dimiliki pegawai, memberikan pengarahan dan bimbingan dalam membantu pegawai dalam melakukan pekerjaan, memberikan beban pekerjaan secara adil kepada setiap pegawai.

c. Untuk pelaksanaan disiplin kerja, maka harus diimbangi dengan penerapan sanksi yang konsisten dan tanpa pandang bulu untuk memberikan efek jera bagi pegawai yang melanggar disiplin sesuai denagn peraturan yang telah ditetapkan pemerintah bagi pegawai negeri sipil (PNS).

d. Sehubungan dengan keterbatasan yang ada pada penulis, sehingga penelitian ini tedapat kelemahan dan mungkin belum bisa mengungkapkan seluruh variabel yang dapat mempengaruhi disiplin kerja pegawai pada Balai Diklat Lingkungan Hidup dan Kehutanan Pematangsiantar. Sebagai bahan masukan untuk penelitian selanjutnya, perlu memperbanyak lagi variabel penelitian.

\section{E. DAFTAR PUSTAKA}

Bangun, Wilson. 2012. Manajemen Sumber Daya Manusia. Jakarta: Erlangga.

Daft, Richard L. 2002. Manajemen. Jilid 1. Jakarta: Penerbit Erlangga 
Handoko, T. Hani. 2002. Manajemen Personalia dan Sumber Daya Manusia. Edisi Kedua. Yogyakarta: BPFE

Hariandja, Marihot T.E. 2006. Manajemen Sumber Daya Manusia: Pengadaan, Pengembangan, Pengkompensasian, dan Peningkatan Produktivitas Pegawai. Jakarta: PT Gramedia Widiasarana Indonesia.

Luthans, Fred. 2005. Perilaku Organisasi. Edisi Sepuluh. Yogyakarta: Penerbit ANDI

Mangkunegara, Anwar Prabu. 2017. Manajemen Sumber Daya Manusia Perusahaan. Cetakan Keduabelas. Bandung: Remaja Rosdakarya

Mathis, Robert L. dan John H. Jackson. 2006. Human Resource Management (Manajemen Sumber Daya Manusia). Edisi 10. Jakarta: Salemba Empat.

Mondy, Wayne R. 2008. Manajemen Sumber Daya Manusia. Jakarta: Erlangga

Northouse, Peter G. 2013. Kepemimpinan Teori dan Praktik. Edisi Keenam. Jakarta Barat: PT indeks

Panggabean, Mutiara S. 2002. Manajemen Sumber Daya Manusia. Cetakan Pertama. Bogor: Ghalia Persada

PP No. 53 Tahun 2010 Tentang Disiplin Pegawai Negeri Sipil

Rivai, Veithzal. 2003. Manajemen Sumber Daya Manusia Untuk Perusahaan. Dari: Teori ke Praktik. Jakarta: PT Raja Grafindo Persada.

Rivai, Veithzal dan Mulyadi Deddy. 2012. Kepemimpinan dan Perilaku Organisasi. Jakarta: Rajawali Press

Robbins, Stephen P dan Mary Coutler. 2010. Manajemen, Edisi Kesepuluh, Jilid 2. Jakarta: Erlangga 